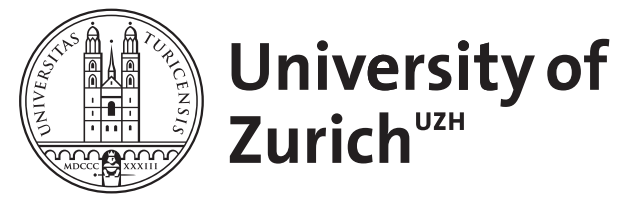

The Global and the Local: Problematic Dynamics of the Triangular Trade in Early Modern Manila

\author{
Tremml-Werner, Birgit
}

DOI: https://doi.org/10.1353/jwh.2012.0095

Posted at the Zurich Open Repository and Archive, University of Zurich ZORA URL: https://doi.org/10.5167/uzh-126006

Journal Article

Published Version

Originally published at:

Tremml-Werner, Birgit (2012). The Global and the Local: Problematic Dynamics of the Triangular Trade in Early Modern Manila. Journal of World History, 23(3):555-586.

DOI: https://doi.org/10.1353/jwh.2012.0095 


\title{
The Global and the Local: Problematic Dynamics of the Triangular Trade in Early Modern Manila*
}

\author{
BIRGIT M. TREMML \\ University of Vienna
}

HANks to a growing awareness of the multilayered ${ }^{1}$ nature of the
South China Sea as a key region in the emerging world trade, the
question of how European overseas performance and local Asian reac-
tion were related to global economic change has gained new momen-
tum in comparative historical studies in recent years. The crucial
question of how the encounters between powerful premodern states
affected economic developments in the so-called European-controlled
port cities has received limited attention. ${ }^{2}$ Late sixteenth-century
Manila, where three premodern states-Spain, China, and Japan-
were simultaneously involved in urban as well as commercial expan-
sion, serves particularly well for such a study. Focusing on triangular

* I would like to thank Ashley Hurst and the anonymous referee of this journal for their comments on an earlier version of this paper. I am also grateful to the Newberry Library for its generous support during the completion of the article.

1 In this essay "multilayered" refers to ethnic, social, and political diversity and to cultural and class differences within one premodern state. State-subject relations were rather complex and not always easy to define. For example, although people from China and Japan often reached the Philippines on a private or illicit mission, they were at least indirectly linked to a state. For the multilayered interactions under examination, notions of "foreign" or "other" play a key role. The term is furthermore used for the pragmatic reason of avoiding occupied terms such as "intercultural" or "multicultural."

2 The author is aware of the potential for debate to what extent Manila or other merchant outposts in Asia were actually "controlled" by European powers given the fact that for all these outposts inter-Asian trade was indispensable, and European sovereignty to a large degree depended on compromises with neighboring powers.

Journal of World History, Vol. 23, No. 3

(C) 2012 by University of Hawai'i Press 
relations in early modern multicultural Manila, this article aims to demonstrate that disentangling Spanish, Chinese, and Japanese operations is the most efficient way of shedding light on the economic and political complexity of the Manila galleon trade that attracted merchants eager to participate in the first truly global commerce in American silver and Chinese silk. The alleged profitability of the Manila trade has been the impetus for previous scholarly research. When we consider that around I600, at least I00,000 kilograms of silver circulated in Manila annually, profit ratios up to 300 or 400 percent $^{3}$ must have had an effect on the economy and most likely also on the foreign affairs of the countries that traded there regularly. ${ }^{4}$

Many scholars nowadays have a gloomy view of the economic performance of Spanish Manila, which is surprising when we look at the trade boom that occurred soon after the Spanish occupation. When it comes to her qualities as trading hub, both seventeenth-century European observers and early twentieth-century American government advisors agreed that Manila had potential for ranking "among the most commercially successful places on the globe." However, Spanish Manila's actual global significance was short-lived and her subsequent downturn has raised many unanswered questions. Its undisputedly rapid success did not result in sustained economic development, neither of the archipelago nor of the city itself. Manila's evolution into a thriving port city of global significance contrasts sharply with her sickly economy in the following centuries. Manila's commercial development raises several questions once we consider that three politically and economically powerful premodern principalities, Spain, China, and Japan, had regular access to the Manila market. ${ }^{6}$ My thesis is that all these states did not take advantage of the location's obvi-

3 According to Alessandro Valignano, the merchants in Manila gained between 400 and 500 percent in the late I 590s. Quoted in Antonio Cabezas, El Siglo Ibérico de Japón. La Presencia Hispano-Portuguesa en Japón (1543-1643) (Valladolid: Universidad de Valladolid, r995), p. 181. See also Chuan Han-Sheng, "Arbitrage, China, and World Trade in the Early Modern Period: Spain and the Manila-Acapulco Galleons," in The European's Entry into the Pacific. Spain and the Manila-Acapulco Galleons, ed. Arturo Giráldez and Dennis O. Flynn (Aldershot, UK: Ashgate, 200I), pp. 24I-260. Chuan estimates profits of Ioo to 300 percent on Chinese silks sold in Mexico.

${ }^{4}$ For a detailed description see the still undisputed classic first published in 1939 by William L. Schurz, The Manila Galleon (Manila: Historical Conservation Society, 1985).

5 Antonio M. Regidor, D. C. L. Jurado, and J. Warren T. Mason, Commercial Progress in the Philippine Islands (Manila: American Chamber of Commerce of the Philippine Islands, I925), p. 2. For premodern accounts on the global economic significance see Juan Grau y Monfalcón, Justificación de la conservación y comercio de las Islas Filipinas (Mexico, I640).

6 I will here use Charles Tilly's straight definition of a state: "When the accumulation and concentration of coercive means grow together, they produce states; they pro 
ous qualities because of differing ideas of sovereignty. In addition, the multilayered encounters in Manila had negative effects on the city's long-run commercial development. In this article I aim to show that Habsburg Spain was unable to take necessary measures because of her permanent lack of settlers, ${ }^{7}$ whereas Ming China, due to its different idea of sovereignty, did not tap the full potential of the tens of thousands of coastal Chinese subjects that visited the Philippine islands annually. Azuchi-Momoyama/early Tokugawa Japan, as the third and often neglected player in early modern Manila, generally showed more interest in controlling Manila than her "big brother" China, but Edo's political centralization program made long-term efforts unnecessary. By the time of intensified Japanese participation in the Manila trade, the newly established military-aristocratic government was busy building its own stable premodern state. At the end of the day, sovereignty at home proved to be more important than overseas expansion.

Against this background we will soon find out that Manila and the Philippines played entirely different roles in these three countries' external trade as well as foreign policies, an insight that even in East Asia has only recently caught researchers' attention. ${ }^{8}$ In this light, the fact that most studies of premodern Manila failed to take into account the influences from China, Japan, and Europe during the 1570 s to the I640s calls for a reevaluation of the mechanism of the Manila market.

\section{The Lure of Global Trade in Manila}

At the end of the sixteenth century, Manila developed into a global trading outpost of major economic and only slightly less geopolitical

\footnotetext{
duce distinct organizations that control the chief concentrated means of coercion within well-defined territories, and exercise priority in some respects over all other organizations operating within those territories." Charles Tilly, Coercion, Capital and European States, $A D$ 990-1990 (Cambridge, Mass.: Harvard University Press, 1990), p. 19.

7 At the beginning of the seventeenth century, the number of Spanish settlers in the whole colony, including soldiers, amounted to some 2,200, at best. The number of households registered in Manila numbered 30o. Luis Merino, The Cabildo Secular or Municipal Government in Manila (Iloilo: Research Center of the University de San Agustin, 1980), pp. $35-36$. In the same period already more than 20,000 Chinese lived in the area around Manila, despite an official order from Spain that their number must not exceed 6,000. The number of Japanese was fluctuating, ranging between several hundreds and 3,00o between the late sixteenth century and the I640s. Iwao Seiichi, Nanyō Nihonmachi No Seisui (Taipei: Taipei Teikoku Daigaku, 1937), pp. 292-300.

${ }^{8}$ See, among others, Igawa Kenji, Daikōkai jidai no higashi ajia: Nichiō tsūkō no rekishiteki zentei (Tokyo: Yoshikawa Kōbunkan, 2007). Ōishi Shinzagurō, ed., Shuinsen to minami he no senkusha (Tokyo: Gyōsei, 1986).
} 
importance for all trading nations involved. Consequently, her urban and economic development became embedded in the complex history of Asia's integration into the global economy ${ }^{9}$ and the Castilian overseas empire's involvement in European and American affairs. ${ }^{10}$ The archipelago's relative closeness to China, Japan, and Southeast Asian trading hubs encouraged these countries' private merchants to call at the favorable natural harbor of Cavite, close to the colonial capital. There they connected to centuries-old trading networks of the wider maritime region spanning far into the Indian Ocean. Coastal Chinese, mostly from southern Fujian, represented the largest group. ${ }^{11}$ The relatively liberal political environment gave rise to allied Japanese and Chinese privateers, the so-called $w a k \bar{o},{ }^{12}$ whose economic activities could-if required-also include coastal raiding. They reached their peak around the middle of the sixteenth century, ${ }^{13}$ at the same time as the Iberians-mostly the Portuguese from the Estado da India, who were prominent on the scene throughout the sixteenth century as pioneers in building a trading post empire in Asia-appeared as promising business partners for the East Asians. ${ }^{14}$

While both economists and historians have tried to trace what caused the Philippines' eventual economic weakness, ${ }^{15}$ how that process was linked to Manila's short-term success in the late sixteenth

9 One of the most recent examples of a maritime macro-region approach is François Gipouloux, La Méditerranée asiatique: Villes portuaires et réseaux marchands en Chine au Japon et en Asie du Sud-Est, XVIe-XXle siècle (Paris: CNRS Editions, 2009).

10 The seemingly endless list includes, for example, hegemonic conflicts with the Portuguese, war with the Dutch, and maritime conflicts with the British.

11 Overseas merchants from Fujian have sometimes been referred to as Hokkien merchants in previous studies. K. J. Chin, "Merchants and Other Sojourners: The Hokkiens Overseas, I 570-1 760" (PhD diss., Hong Kong, 1998). Under the label of 華僑 huáqiáo (Ch.)/kakyō (J.), their history has been researched in East Asia.

12 倭寇 wokou (Ch.) or wakō (J.) literally means "Japanese bandit." But most of the time, these groups included a larger number of Chinese than Japanese people.

${ }_{13}$ Maehira Fuseaki, "Minchō no kaikin seisaku to Ryūkyū kaikin: Wakōron wo chūshin ni," Kōtsūshi kenkyū 67 (2008): 6r-76.

${ }_{14}$ For the Lusitanian network of merchant outposts and its early success based on military superiority over Asian business partners see Philip D. Curtin, Cross-Cultural Trade in World History (Cambridge: Cambridge University Press, I984), in particular chapter 7.

${ }^{15}$ Leslie E. Bauzon, Deficit Government: Mexico and the Philippine Situado, I606-1804 (Tokyo: Centre for East Asian Studies, 198I); John L. Phelan, The Hispanization of the Philippines: Spanish Aims and Filipino Responses, 1565-1700 (Madison: University of Wisconsin Press, 1959). For a reassessment of Bauzon's accounts see Luis Alonso, "Financing the Empire: The Nature of the Tax System in the Philippines, I565-1804," Philippine Studies 6I, no. I (2003): 63-95. For a narrative that examines the Manila trade simply as trade between Mexico and the Philippines see Oskar H. K. Spate, The Spanish Lake: The Pacific since Magellan (Minneapolis: Minnesota University Press, 1979), pp. 2 I 8-228. 
century remains still partly unanswered. ${ }^{16}$ Scholars like Leslie E. Bauzon claim that the prosperous years of the export-oriented commercemainly based on the Manila galleon trade-consequently hindered the further economic development of rural regions and other business sectors due to the easy availability of money pouring in from the Americas. Others seem convinced that the poor economic development was more the result of unreasonable Spanish governance and less the product of the multilayered nature of the area. ${ }^{17}$ Both viewpoints acknowledge Manila's outstanding economic performance around I600. As an interface between imperial Spain, Ming China, and Japan, Manila grew into a global port city by linking various world markets by the end of the sixteenth century. Why did the short-term success not mark the beginning of a period of prosperous development?

\section{Long-Term versus Short-Term Effects}

Dennis O. Flynn and Arturo Giráldez, probably the most assertive advocates of early modern Manila's "miracle," consider the foundation of the Spanish colonial city in $157 \mathrm{r}$ as the point when global trade was born. In their much-quoted article about the impact of intercontinental silver flows on world affairs, they claimed that "Manila was the crucial entrepôt linking substantial, direct, and continuous trade between the Americas and Asia for the first time in history." ${ }^{18}$ As such, late sixteenth-century Manila, as the Asian outpost of the Manila galleon trade, became a center for intercontinental exchange of Americanand to a certain extent also Japanese-silver and Chinese silks and ceramics. ${ }^{19}$ Yet, as has been the case in several other works dealing with the Philippines, while highlighting Manila's remarkable growth at the time, they provide a very bleak view of Spanish performance in Asia.

${ }^{16}$ For an insightful picture of the transpacific bullion cargoes, Chaunu's study is still unchallenged. Pierre Chaunu, Les Philippines et le Pacifique des Ibériques (XVIe, XVIle, XVIIle siècles) (Paris: SEVPEN, 1960).

17 John Villiers, "Portuguese Malacca and Spanish Manila: Two Concepts of Empire," in Aspects in History and Economic History (Sixteenth and Seventeenth Centuries), ed. Roderich Ptak, pp. 37-57 (Stuttgart: Steiner, 1987). Charles R. Boxer, "Plata Es Sangre: Sidelights on the Drain of Spanish-American Silver in the Far East 1 500-1 700," Philippine Studies I8, no. 3 (I970): 457-478.

18 Dennis O. Flynn and Arturo Giráldez, "Born with a Silver Spoon: The Origins of World Trade in I 57I," Journal of World History 6 (1995): 201.

${ }^{19}$ For Japanese silver contributions to Ming China see Nakajima Gakushō, "Jyūrokusekimatsu no Fukken-Firipin-Kyūshū bōeki," Shien I 44 (2007/2009): 55-92. 
For decades, the conventional wisdom has been that the cities' economic success was simply and solely a result of foreign parties' exchanging highly priced commodities; in other words, this would mean that the city existed only because of its function as a transit port. Sinocentrists and followers of the California school claim that this sort of exchange was a losing deal for the exporting countries and intermediaries, since the silver eventually all ended up in China. ${ }^{20}$ Thus, Manila has been considered nothing more than a way station to China and the bullion flows from America were a losing deal for the Spanish. ${ }^{21}$

For the Spaniards, as colonial rulers, restricting East Asian participation in this exchange was not an option, for the latter secured the colony's military and general supply.22 Importing military resources from China, Portuguese Macau, and Japan was necessary from the earliest days of the colony but became especially important at the beginning of the seventeenth century, when the Spanish were exposed to continuous Dutch attacks. ${ }^{23}$ The Portuguese role in the Manila trade was ambiguous: despite logistic interdependence, the Spaniards also tried to limit Portuguese interaction as a result of restricting trade at Manila. A law of 1593 prohibited Castilians from trading in Macau, and Spanish sources furthermore hint at royal decrees that forbade Macau traders in Manila. However, these regulations were eased in the I620s when Portuguese started to travel from Macau to Manila on a regular basis and started to carry huge amounts of silver to China. ${ }^{24}$ Since they lacked a permanent base in Manila, they will not be treated in this article.

${ }^{20}$ During the Ming period, China's demand for silver increased due to a permanent outflow of copper coins. Together with the tax reforms and a stagnating domestic production, China became financially dependent on silver imports. For the ideas of those historians see Peer Vries, "The California School and Beyond: How to Study the Great Divergence?" Journal für Entwicklungspolitik/Austrian Journal of Development Studies 24, no. 4 (2008): 6-49, in which he shows that "members" of the California school tend to overlook major institutional differences between China and the West.

${ }^{21}$ For China as "silver sink" see Flynn and Giráldez, "Born with a Silver Spoon," pp. 20I-22 I. Andre Gunder Frank, Reorient: Global Economy in the Asian Age (Berkeley: University of California Press, I998), pp. I3 I-I65. See also Richard von Glahn, Fountain of Fortune: Money and Monetary Policy in China, I000-1 700 (Berkeley: University of California Press, I996); William S. Atwell, "Another Look at Silver Imports into China, I635I644," Journal of World History i6, no. 4 (2005): 467-49i.

${ }_{22}$ Maria Lourdes Díaz-Trechuelo, Filipinas: La gran desconocida (1565-1898) (Pamplona: Ediciones Universidad de Navarra, 200I), pp. 7 I-82.

${ }_{23}$ For a recent study on early modern Japanese military contributions on a global stage see Adam Clulow, "European Maritime Violence and Territorial States in Early Modern Asia, I600-1650," Itinerario 33, no. 3 (2009): 72-94.

${ }_{24}$ Schurz, Manila galleon, pp. I IO-I I 4 ; von Glahn, Fountain of Fortune, p. I 24. 
Most attractive for Chinese and Japanese merchants who flocked together to Manila was that like other port cities around I6oo, such as Hoi-An in modern Vietnam or Ayutthaya in Thailand, it offered them a "neutral setting" 25 where they could escape the usual supervision of their respective states. Private merchants from both countries welcomed the opportunity offered by such new trading centers outside their native countries, since Japan, despite the legalization of Chinese maritime trade in 1567 , still remained a nation non grata. The Japanese were still prohibited from entering China, while the Chinese were likewise not allowed to travel to Japan on official trade missions. ${ }^{26}$ With their regular voyages to the coasts of Luzon, Fujianese and Japanese contributed to Manila's urban development from her earliest days. What led them to Manila was personal economic motives, indirectly encouraged by their states. Oddly enough, notwithstanding the manifold trade patterns and the short-term profits of private traders and smugglers, neither Manila nor the three vigorous premodern states involved gained much in the long run. Nor did they take lasting advantage of Manila's unprecedented possibilities at the end of the sixteenth and the beginning of the seventeenth century. The question is why they did not. Having defined premodern Manila's nature, we move on to analyzing this main paradox.

\section{A Multilayered Analysis of the Manila Trade AROUND I 600}

Despite being characterized by a central government interested in monopolizing power, it seems that neither Spain nor China nor Japan tried to channel the obvious profits from the Manila trade into the respective state's budget. In spite of the "generative role of the galleons," 27 the economic reality of the early decades was rather disillusioning: merchants had the impression that they could not make the most of it, mutual mistrust poisoned the politico-economic climate in Manila, and the Philippine economy ended up unable to sustain itself. Accordingly, one gets the impression that things had gone wrong.

25 Von Glahn, Fountain of Fortune, p. I21.

${ }^{26}$ John E. Wills, "Maritime China from Wang Chih to Shih Lang," in From Ming to Ch'ing, ed. Jonathan D. Spence and John E. Wills Jr. (New Haven, Conn.: Yale University Press, I979), p. 2 I I.

27 Robert R. Reed, Colonial Manila: The Context of Hispanic Urbanism and Process of Morphogenesis (Berkeley: University of California Press, 1978), pp. 27-35. 
Concerning Manila itself, one is even tempted to conclude that, economically speaking, the trilateral relations did more harm than good.

Policymakers neither made the most of any benefits from the early modern market economy nor did they maximize the advantages of having access to both transpacific and inter-Asian exchange that undoubtedly led to an increase in exchange and consumption. Stressing the profitability of long distance trade in luxury goods and the large revenue deriving from such economic activity, Fernand Braudel characterizes the individual groups taking part in early modern long-distance trade as entrepreneurs who "chose whatever would maximize [their] profits." 28 But compared to, for example, "the fantastic rise of Amsterdam," 29 Manila turned out to be both a mercantilist and a proto-capitalist disappointment. By the midst of the seventeenth century, license fees and other revenues taken from foreign trade had declined. ${ }^{30}$ What happened? Accordingly, the prevailing view has been that the Spanish economic performance in the Philippines was a disaster. ${ }^{31}$ To a large extent that is due to numerous scholars accepting the leyenda negra narrative, ${ }^{32}$ which, as I hope to show, misrepresents the Spanish Crown and her subjects as inefficient. Besides, the tendency to look at the Philippines in isolation has prevailed up to the present day. It is therefore no surprise that the Spanish economic performance in the Philippines has been misinterpreted.

I believe that the role of the state embedded in global-local dualism was instrumental for port cities like Manila. Economically, neither Spain nor China nor Japan benefitted from the Manila trade. Hence we have to ask what these three premodern states did or did not do that resulted in the failure of Manila to develop into a permanently impor-

${ }^{28}$ For Braudel's ideas on long-distance trade as ultimate exchange pattern see Civilization and Capitalism, 15th-18th century, vol. 2., The Wheels of Commerce (London: Collins, I982), pp. 55-56, 400-428.

29 Fernand Braudel, Afterthoughts on Material Civilization and Capitalism (Baltimore: Johns Hopkins University Press, I977), p. 26.

30 See the figures on tribute, almojarifazgo, and other income presented by Luis Alonso, one of the few scholars who questioned the early modern Philippines' fiscal debit ("Financing the Empire," pp. 7I-73). In his study he has moreover shown that the idea of the Philippines being a financial burden for Spain had existed since the earliest colonizing efforts.

31 Bauzon speaks of a "fiscal nightmare" in Deficit Government, pp. 20-26.

32 The so-called black legend, a term coined by Julían Juderías in the early twentieth century, refers to an anti-Spanish propaganda that dates back into the times of the Revolt of the Netherlands in the sixteenth century and experienced several revivals throughout history. Such propaganda accused the Spanish of, among other things, ruthlessly spreading Catholicism and political tyranny during the reign of Philip II (r. I556-1 598). Joseph Pérez, La leyenda negra (Madrid: Gadir Editorial, 2009), pp. 53-139. 
tant trading hub. Answering this question requires a comparative study of their political economies.

\section{The local and Central Levels of the Multilayered Analysis}

This exploratory article will pinpoint global and local connections on a specific geographical stage and seeks to trace Spanish, Chinese, and Japanese engagement in Manila by reassessing their commercial interactions and various Manila-related trade patterns at the end of the "long sixteenth century." 33 Accepting the established belief that the Spanish-born population of Manila did not benefit from the obvious riches of the galleon trade, we have to ask: who did? We know that Chinese, Japanese, and Portuguese participated-both in legal and illegal trade-despite constantly complaining about insufficient returns. ${ }^{34}$ Neither Japanese nor Chinese commercial activities showed any signs of serious decline until the beginning of domestic political transformations in the I620s and I640s, respectively. Revisiting the early years in the history of the Spanish colonial capital with a special focus on disentangling the various levels of interaction should shed light on their complex relations and the dynamics behind them.

The attitudes and motivations of these three countries toward Manila were on the whole different. My point of departure is that the striking differences in political economies and culture are very important considerations when analyzing the behavior of states. ${ }^{35}$ In each of these three premodern states we find a single hereditary ruler who reigned over a specific sovereign territory with a largely agrarian economy. Governance was supported by sophisticated bureaucratic struc-

33 The study is based on official orders and decrees concerning foreign relations and looks at whether or how they affected individual traders, settlers, or other visiting parties.

34 See Ming Shi-lu, Zhong-yang Yan-jiu yuan, I610-1 I-29: "Recently, as trading with Japan has been far more profitable than trading with Luzon, some evil persons bribed the local officials who issued warrants without authorization, and they went to sea as they wished." Geoff Wade, translator, Southeast Asia in the Ming Shi-lu: An Open Access Resource (Singapore: Asia Research Institute and the Singapore E-Press, National University of Singapore), http://epress.nus.edu.sg/msl/entry/3205/, accessed I March 201 I. (Henceforth cited as Ming Shi-lu.)

35 I here endorse Adam Smith's classic definition of political economy as "a branch of science of a statesman or legislator that proposes to enrich both people and the sovereign." Adam Smith, An Inquiry into the Nature and Causes of the Wealth of Nations, ed. R. H. Campell and A. S. Skinner (Indianapolis: W. B. Todd, I98I), pp. 678-679. 
tures. ${ }^{36}$ So we may be tempted to conclude that both economically and politically, differences between late sixteenth-century China, Japan, and Spain were marginal. However, they seem to increase significantly when we take on board the effect of cultural influences and geopolitical considerations on their political economies. Multilayered encounters in Manila reveal major differences both in mode of governance and the institutions that backed their respective political economies. Intrigued by this idea of striking differences between the maritime powers of the South China Sea, I should briefly compare Spain's, Japan's, and China's sixteenth-century presence in Manila before continuing with a comparative analysis of their political economies.

\section{SPAIN}

Spanish colonial rule in sixteenth-century Southeast Asia was characterized by a very fragile power structure. The Spaniards were engaged in endless struggles with indigenous populations to impose rule in the archipelago's hinterland. In addition, their sovereignty had already met its limits inside Manila, due to demographic weakness. Despite being the nominal rulers of the Philippines, from a politico-economic point of view and in terms of actual power, with the small number of about two thousand Spanish colonizers, Spain was merely one among many actors on the Southeast Asian scene. Economic hardship and political transitions in the metropolis as well as constant involvement in hegemonic competition in Europe and the Americas enormously complicated the position of the overstretched empire. When the conquistadores arrived in northern Luzon in 1570, a Muslim clan under Rajah Sulaiman III was ruling the Manila Bay area. Intrigued by the small trading port's convenient location, which offered access to both the hinterland and the maritime trade, the Castilians immediately occupied the territory and founded a colonial settlement. ${ }^{37}$ Within a few years it turned into a prosperous port city, attracting the attention of early modern global players from China, Japan, as well as Portugal and Northern Europe.

36 See Jack A. Goldstone, Revolution and Rebellion in the Early Modern World (Berkeley: University of California Press, i99i), p. 4 .

37 Maria Lourdes Diaz-Trechuelo, "Legazpi y la Integración de Filipinas en el Imperio Español de Ultramar," in Filipinas, Puerta de Oriente. De Legazpi a Malaspina, ed. Alfredo José Morales Martínez (Madrid: Sociedad Estatal para Acción Cultural Exterior, 2003), pp. 49-66. 
Manila thus became part and parcel of the emerging world economy. ${ }^{38}$ After his hopes to find an abundance of spices or precious metals were frustrated soon after landing on the archipelago in 1565 , the first governor of the Spanish colony, Miguel López de Legazpi (r. 1569-1572), was of the opinion that only the trade in Chinese silks could make up for the failure to create a monopoly on the spice trade and therefore proposed this strategy to his king. ${ }^{39}$

After Andrés de Urdaneta and his crew eventually succeeded in finding a return route (tornaviage) via the Pacific to Mexico, cargos with provisions and silver were annually sent from Acapulco to Manila until 1815-that is, just before Mexico gained independence from Spain. With the huge bullion flows that reached Southeast Asia after the discovery of the transpacific route and the establishment of a regular transport network between the two coastal colonial outposts, the Spanish in the Philippines were able to quench China's thirst for silver but at the same time had difficulties maintaining the colony and were far from achieving what a few individuals dreamt of: neither Spanish rule nor the Catholic faith were noticeably spread beyond the archipelago's borders. ${ }^{40}$ The fact that it did not accomplish any initial imperial goals in the East has often led to the conclusion that Spain had ignored Manila's obvious qualities as an emporium for transcontinental trade. This, however, is a one-dimensional argument. The Spanish may have been short-sighted in economic affairs, but what they missed most in the Philippines was simply the people who could carry out elaborate jobs. For instead of taking advantage of maritime Asia's economic conditions, the territorial colonial model—which had just been successfully tested in the Americas - was uncritically applied to the Philippines despite the far greater distance between the Philippines and the motherland. As with the Americas, early steps in colonizing the region were achieved by missionary efforts and the administrative and educational contributions of the friars, who were not only the first but

38 For Asian and European contributions to Southeast Asian port cities' florescence see Leonard Y. Andaya, "Interactions with the Outside World and Adaptation in Southeast Asian Society 1 500-1800," in The Cambridge University of Southeast Asia c. 1500-c. I 800, vol. I, part II, ed. Nicholas Tarling (Cambridge: Cambridge University Press, 2004), pp. $\mathrm{I}-57$.

39 Andaya, "Interactions," p. I3.

40 What shaped this narrative was Governor Francisco Sande's (r. I575-1580) bold plan of the year I 576 to conquer China with a force no larger than six thousand men, as well as restless attempts by Padre Alonso Sanchez to establish missionary posts in China. See Archivo General de Indias (henceforth cited as AGI) Filipinas 6, r. 3, n. 26, "Carta de Sande sobre corsario Limajón, reino de Taibin, etc." ( 7 June i 576). 
also the most committed Spanish settlers of the Philippines. ${ }^{41}$ Because of frequent natural disasters, such as fires and earthquakes, seasoned Spanish town planners were not able to build a solid town until the seventeenth century. Despite residential restrictions imposed by the ruling Spaniards, the tens of thousands natives, Chinese, and Japanese who settled around the city walls were integrated well into the urban structure. From the very beginning, Manila's settler continuity relied on migration from East Asia as well as logistical support from outside. After the native population of the archipelago, people from Chinaincluding visiting and hibernating merchants and sailors, as well as long-term residents and immigrants-represented by far the hugest ethnic group in Manila. ${ }^{42}$

Without doubt, the influx of cheap silk to the American markets was the most obvious contribution of the Philippines to the Overseas Empire. ${ }^{43}$ Bought in Manila, brought back by the Manila galleon, and distributed at American fairs, Chinese silk was just as much a global commodity as American silver. Spanish government documents show that silk industry losses had the potential of turning into a fundamental problem for the Crown. Therefore this trade pattern was not welcomed by all. Merchants and economic groups back home as well as in Mexico often protested against this unfair competition. More silk from Asia meant decreasing sales figures for the silk from the motherland. Since whole regions in Granada and Valencia depended economically on the export of silk to the Americas, the importation of Chinese silks seriously harmed the local Spanish and Mexican industry and at times even caused bankruptcy. ${ }^{44}$ The influx of cheap Chinese silk therefore simply was not compatible with the existing transatlantic system. ${ }^{45}$ When those living from the sericulture business started caus-

41 Maria Lourdes Díaz-Trechuelo, "The Role of the Chinese in the Philippine Domestic Economy (1570-1770)," in The Chinese in the Philippines 1570-1770, vol. I, ed. Alonso Felix Jr. (Manila: Solidaridad, I966), pp. 206-208.

42 See also n. 7 .

43 Reed, Colonial Manila, p. 30.

44 Archivo General de Simancas, PTR. LEG. 89, doc. 298, "Memorial del Reino pidiendo la prohibición de la importación de seda de China y Persia" (August i6 i 7 ).

45 The exact amount of Chinese silk that entered the Americas in the late sixteenth and early seventeenth centuries is hard to calculate. In I 598 Francisco de Tello (r. 1596I602), governor of the Philippines, remarked in a letter to King Philip II that the Chinese merchants who came to Manila to trade, sold cheap silk for the total amount of eight hundred thousand to I million pesos. We also know that during the first decade of the seventeenth century two or three boxes of Chinese silk were sold for one thousand pesos. Yet, by the I62os, increasing competition with the Dutch caused prices to double, and merchants were often reported to complain about a shortage in Chinese raw silk for the manufactures 
ing a period of constant social movements and civil protest, ${ }^{46}$ the central government had to take action. Considering Spain's involvement in European affairs and uprisings on the peninsula, it will come as no surprise that the king favored peace and military support at home over economic gains in faraway places-a situation that made it difficult to react to changing demands within the vast overseas empire. Peru's banning of direct trade with Manila has to be understood as a measure against the colonial society in the Americas that was feared to become economically independent from the Spanish motherland. ${ }^{47}$ Competition among merchants of the overseas empire should be understood against this background. Although local Spanish merchants in Manila were in theory protected by the boleta system of the galleon trade, Mexican merchants were in practice in a privileged position thanks to their direct access to silver. ${ }^{48}$

\section{China}

For an accurate assessment of China's presence in Manila, it is crucial to distinguish between official Ming China and the aforementioned local groups from Fujian. On the one hand, official relations had existed since the early days of the Ming dynasty, when China's traditional tributary system became intertwined with economic and social developments in Southeast Asia. On the other hand, we find a huge group of so-called overseas Chinese who navigated the South China Sea, reaching ports in Luzon and Cebu long before the arrival of the Europeans. ${ }^{49}$ Several historians as well as social scientists have shown that Chinese private foreign trade increased as a consequence of the

in New Spain. See The Philippine Islands I 493-1898, ed. Emma Helen Blair and James Alexander Robertson, 55 vols. (Cleveland: Arthur H. Clark, I 905), I0: I 79. Taking von Glahn's silver figures of approximately 5 million pesos ( 127,800 kilograms), this would mean that about one fifth of the American silver was spent on silk. The impressive size of the silk market in Manila, which spread over four large buildings, gives further evidence for the profitability of the silk trade. See Blair and Robertson, Philippine Islands, 7:220.

46 Spain suffered from the expulsion of the Moriscos as well as regional autonomy movements during the reign of King Philip III (r. I 598-162 I).

47 AGI, Filipinas 339, 1. 2, f. 7or - 7Ir, "Orden al Virrey de Perú sobre prohibición de comercio" (I I January I 593 ).

${ }^{48}$ For a synthesis of Manila's integration in long-distance commerce see Katharine Bjork, "The Link That Kept the Philippines Spanish: Mexican Merchant Interests and the Manila Trade, I 57 I-I 8I 5," Journal of World History 9 ( I998): 5I-88.

49 William Henry Scott, Barangay. Sixteenth-Century Philippine Culture and Society (Quezon City: Ateneo de Manila University Press, 1994). 
country's pressing need for silver as a means of payment during the sixteenth century, in particular the effects of the Single-Whip reform. This change in China's fiscal system, which implied that in principle all land taxes be paid in silver, is regarded as a turning point in world history, for it integrated China into the emerging global economy. ${ }^{50}$ According to moderate estimates, one hundred thousand kilograms of silver left Manila for China annually at the turn of the sixteenth century. In light of this, Manila's role in the late Ming's economic history will become clearer. As a reaction to the necessity of importing ever greater amounts of silver, the Ming government eventually suspended the official prohibition on foreign maritime trade in 1567 , and a certain number of licensed trading vessels would soon be sent to Luzon. ${ }^{51}$ Since official foreign trade remained strictly controlled thereafter, only a minor part of the formerly illicit trade activities in the South and East China Sea region was absorbed by it. Due to both licensed and illegal silver imports to China, several hundred Fujianese traders traveled to Manila annually after I57 I, and it was not only the silver that lured them. Fujianese traders had participated actively in inter-Asian trade for a long time and could rely on an already existing widespread trading network in East and Southeast Asia. This explains why soon after Spanish reign was established over the archipelago, the colony's first governor, Miguel de Legazpi, informed King Philip II about Chinese junks calling on ports in Luzon. ${ }^{52}$ In that respect it will not come as a big surprise that they became the real colonizers of Manila. During the sixteenth century, people from several regions of coastal China emigrated from economic pressures such as poverty, ${ }^{53}$ a hardship they would not suffer in Manila, where the Chinese community would come to dominate the majority of the business sectors, ranging from retail to the building and service industries. ${ }^{54}$ When the number of immi-

50 William Atwell, "Ming China and the Emerging World Economy, c. I470-1650," in The Cambridge History of China: The Ming Dynasty, 1368-1644, ed. Denis C. Twitchett and Frederick W. Mote (Cambridge: Cambridge University Press, I998), p. 4 I 6.

51 Von Glahn, Fountain of Fortune, pp. I I 9-123. Over the decades, studies on early modern silver flows have led to controversial results and debates due to the scarcity of reliable quantitative data.

${ }_{52}$ Cited in Reed, Colonial Manila, p. 3 I.

53 For the economic importance of the sixteenth-century southern Chinese diaspora see Wang Gungwu, "The China Seas: Becoming an Enlarged Mediterranean," in The East Asian 'Mediterranean': Maritime Crossroads of Culture, Commerce and Human Migration, ed. Angela Schottenhammer (Wiesbaden: Harrassowitz Verlag, 2008), pp. 7-22.

54 Alberto Santamaria, OP, "The Chinese Parian (El Parian de los Sangleyes)," in The Chinese in the Philippines I570-1770, ed. Alonso Felix Jr. (Manila: Solidaridad, I966), p. 90: Governor Dasmariñas writing in a letter to King Philip II, I591: "Within the city is the silk-market of the Parian where the Chinese merchants trade. They have 200 stores, which probably employ more than 2,000 Chinese." 
grant Chinese sangleyes - a pejorative term used by the Spaniards for members of Fujianese merchant communities that originated from a mispronunciation of chang lai (those who come frequently) or shang lai (those who come to trade) ${ }^{55}$-had reached several thousands, they were assigned their own quarter, the Parian, in the early I 580 s. ${ }^{56}$ However, many Chinese merchants and artisans retained their shops within the city itself.

It is small wonder that the scales of interdependence between Europeans and Chinese soon tipped under the weight of increasing influence wielded by the Chinese. ${ }^{57}$ Fear of the huge number of Chinese immigrants seemed to prove right when the colony experienced its first military attack from the sea. In the year I 574, a group of pirates led by Lin Feng launched an attack on Manila, after their attempts to take over parts of the Guangdong coast and Hainan Island had been frustrated. The story of Lin Feng, who would be erroneously recorded in European sources as Limahon, has mostly been presented as a unique story of an evil Chinese outlaw who tried to conquer the young Spanish settlement in Manila with his fellow pirates. The dominant discourse stressed the Castilians' heroic defense of what they considered their property and territory. According to European records, the Spanish commander Juan de Salcedo and his men defeated Lin Feng's pirate force of seventy ships and more than three thousand invaders, before a fleet under Wang Wangguo was sent from China-where Lin Feng and his fellow pirates had long been fruitlessly chased-to support the Spanish. ${ }^{58}$ Recent research carried out by Igawa Kenji, who added an East Asian perspective by scrutinizing Chinese records, has brought to light Lin Feng's incorporation into wakō networks. ${ }^{59}$ What is interesting about Lin Feng's attempt to conquer Manila is not the actual military threat but its long-lasting impact on Castilian collective memory and anti-Chinese propaganda trans- and cis-pacific. ${ }^{60}$

\footnotetext{
55 See Manuel Ollé, La Empresa de China (Barcelona: Acantilado, 2002), pp. $244,263$.

${ }^{56}$ Records on the establishment of the first parian vary between 1579 and ${ }_{5} 58 \mathrm{I}$. In the course of the seventeenth century Chinese settlements increased so that one could find different parians in the surroundings of Manila.

57 Leonard Blussé van Oud-Alblas, Strange Company: Chinese Settlers, Mestizo Women and the Dutch in VOC Batavia (Leiden: Brill, 1986), p. 78.

${ }_{58}$ Ollé, Empresa, p. 56

59 Igawa Kenji, "At the Crossroads: Limahon and Wakō in Sixteenth Century Philippines," in Elusive Pirates, Pervasive Smugglers. Violence and Clandestine Trade in the Greater China Seas, ed. Robert J. Anthony (Hong Kong: Hong Kong University Press, 2010), p. 8o.

${ }^{60}$ Edward R. Slack, "Sinifying New Spain. Cathay's Influence on Colonial Mexico via the Nao de China," in The Chinese in Latin America and the Caribbean, ed. Walton Look Lai and Tan Chee-Beng (Leiden: Brill, 2010), pp. 7-34. Even in Mexico Lin Feng's defeat was solemnly commemorated.
} 
Yet it was not only external attacks that jeopardized relations between the European colonial capital and Chinese settlers. Over the years, frictions between Chinese settlers and the governing body led to tensions and distrust, which at times erupted into violent uprisings. A whole series of incidents started with the assassination of governor Gomez Perez Dasmariñas (r. I 590-1 593) and other Spaniards by Chinese rowers employed on one of the Spanish imperial enterprises to the Moluccas in I 593. ${ }^{61}$ This mutiny had its origins in Chinese ill feeling about being forced to work on the galleys. By 1596 governing the high number of Chinese settlers in Manila had become so challenging that colonial authorities were left with no other option than expel the majority of sangleyes. ${ }^{62}$ In reality, this measure did not materialize, and social peace remained fragile.

The situation eventually escalated in 1603 . In that year, tensions increased even further in reaction to the arrival of three mandarins searching for the legendary gold mountains of Cavite, a move misinterpreted as a sign for a possible and long-feared Chinese invasion. When a fire broke out in the Chinese Parian, fate took its course. Much has been written on the subsequent uprising of the Chinese and the severe punishment handed out by the Spaniards, who were accused of having slaughtered several thousand people. It is hard to ascertain what exactly happened, for accounts on the event differ largely depending on the standpoint of the authors. ${ }^{63}$ The Spanish are reported to have burnt the Chinese silk market, the alcaicería ${ }^{64}$ in the heat of the moment, after having noticed that inhabitants of the neighborhood were preparing for an attack. During the following weeks, joint Spanish-Filipino and Japanese forces supposedly killed between fifteen thousand and thirty thousand Chinese. ${ }^{65}$ Despite the circulation of such figures in both Chinese and Western circles, there is no concrete evidence to support such huge numbers. First and foremost, we do not know the exact figure of Fujianese settlers in r603. Even if it had doubled the officially

${ }^{61}$ Quoted from José Eugenio Borao, "The Massacre of 1603 : Chinese Perception of the Spanish on the Philippines," Itinerario 23, no. I (I998): 24.

62 Blair and Robertson, Philippine Islands, 9:266.

63 AGI Filipinas 7, r. I,n. I2, "Carta de Acuña sobre sublevación de sangleyes, galeras" (8 August r603); AGI, Filipinas 35, n. 68, "Carta de Juan de Bustamante sobre la sublevación de los sangleyes" ( 8 December ı603); AGI, Filipinas, I9, r.6, n. 91, "Carta de audiencia sobre asuntos de gobierno" (30 June 1605 ).

64 AGI, Filipinas 84 , n. I 18 , "Carta del cabildo eclasiástico de Manila sobre sublevación de sangleyes" ( i I December I603).

${ }_{65}$ AGI, Filipinas 7, r. I, n. 28, "Carta de Acuña al virrey de Ucheo sobre castigo a sangleyes" (August 1605). 
permitted number of six thousand and if we take into account several hundred visiting merchants, we could not reach such a high number. Given insufficient ammunition the Spanish population would, despite Japanese and Filipino support, not have had the means for such a drastic punishment. So where do these numbers come from? My estimation is that they originate from three concurring factors: the Castilian side exaggerated the number for the sake of demonstrating military superiority, the Chinese side indulged in playing the role of victim, and other hostile parties of the Spanish, such as the Dutch, welcomed such exorbitant numbers for their anti-Spanish propaganda.

What we know for certain is that after these dreadful events the Spanish colony in Manila for months suffered under the collapse of the entire network of supply that was built on sangley merchants and manufacturers. ${ }^{66}$ Fujianese immigrants had long been accepted as the economic pillar of the colony and consequently were welcomed to resettle the Parian and to return to their previous occupations because the Spanish needed the networks reestablished. ${ }^{67}$ By i 606, I,500 resident permits had been issued again, and another source registers 6,533 visitors from China in the same year. ${ }^{68}$ After only a few years, things had returned to normal and, just as prior to I603, the Chinese would cater to the needs of intramuros, by producing clothes in the latest Spanish fashion and baking the daily bread. In addition, craftsmen back home in Fujian and Canton contributed to quench the new American elite's thirst for luxury items, which were especially appreciated for their good price $^{69}$

The other side of the coin of the 1603 events is that the Ming emperor let down his expatriates and refused to avenge the unrighteousness that had happened to them. Spanish sources indicated that an official Chinese statement on the events was sent to Manila from Fujian. In this letter the emperor threatened the Spanish that they would send a large fleet to Manila unless the value of the goods carried there by Chinese merchants in 1603 was returned to them. ${ }^{70}$ However,

${ }^{66}$ AGI, Filipinas 27, n. 48, "Carta de la ciudad de Manila sobre comercio, japoneses... etc." (9 July I604).

${ }^{67}$ AGI, Filipinas 74, n. 58, "Testimonio de Luis de Salinas sobre sangleyes" ( 5 June I606); Blair and Robertson, Philippine Islands, I4:1 5 I, I89-191.

${ }^{68}$ Díaz-Trechuelo, "Role of the Chinese," p. I84.

${ }^{69}$ Chuan, "Chinese Silk," p. 249.

70 AGI, Filipinas 7, r. I., n. 28, "Carta de Acuña al virrey de Ucheo sobre castigo a sangleyes" (August I605) 
there was no mention of the civil losses. The Son of Heaven considered the settlers of these overseas communities subjects of the rulers of Luzon rather than people of China. To the upset Fujianese local authorities, the emperor made clear that he would not wage war for the sake of ordinary merchants, even less to avenge something that had happened outside China. ${ }^{71}$ The emperor's only reaction was to ask the audiencia, the highest court in Manila, to serve up justice ${ }^{72}$ - a request that illuminates that Ming China had a different idea of its role in foreign affairs.

In light of central China's half-hearted and hesitant reactions to the events in Manila, I have to disagree strongly with Edward Slack's estimation that without Japanese military assistance-although we can only speculate as to the motives behind it, such as competition between Japanese and Chinese merchants, or pent-up hostility after Hideyoshi's unsuccessful Korea invasion or even fear of Spanish repressions- "Sangleyes would surely have made the Philippines a colony of the Middle Kingdom." ${ }^{13}$ Neither the merchants themselves nor the central rulers tried to politically integrate mercantile outposts into China.

\section{JAPAN}

It is now time to turn to Japan's role in the Manila trade, which has too often been overlooked. Fully grasping the complexity of the entanglements at the end of the late sixteenth century, without considering Japanese activities, however, is impossible. As with Ming China, the Japanese presence in Manila was characterized by the dualism of local and central interests. Japan's entry into Southeast Asia is closely intertwined with China's economic history. When Japan's tributary trade relations with China ended in the I530s, Japanese traders had to find new ways to take part in maritime trade. Soon piracy and smuggling carried out by merchant adventurers-commonly referred to as wakō-

${ }^{71}$ Quoted from Borao, "Massacre," p. 33.

72 AGI, Filipinas 74, n. 6o, "Testimonio de memoriales de Benavides sobre sangleyes" (7 July I605).

${ }^{73}$ Edward R. Slack Jr., "The Chinos in New Spain: A Corrective Lens for a Distorted Image," Journal of World History 20, no. I (2009): 50. In his long overdue effort to bring light into the immigration of Fujianese onboard the Manila galleons to Mexico, this author regrettably blinds out the different levels of the local and the central in these intercultural processes. 
reemerged. During the days of political and economic transformation at the end of the civil war period around the middle of the sixteenth century, they seized the opportunity to merge with southbound Chinese traders for joint operations. ${ }^{74}$ By supporting these merchant groups, Japanese local lords, daimyō, seeking to extend their political influence, became acquainted with the Europeans in the South China Sea. In the course of the subsequent decades of nanban trade-as the Japanese called their commercial intercourse with the "barbarians" located south of Japan-regular trade patterns of both local and central origin came into existence ${ }^{75}$ Local lords of the southern island, Kyūshū, were the first to make advances in establishing regular ties with the Spanish in the Philippines, thus becoming an integrated part of the Manila trade in the 1580 s. $^{76}$ Committed to establishing business relations, Iberian missionaries were welcomed in Japan, and, in return, local merchants were given access to European-dominated ports. Roughly at the same time, a Spanish force expelled a group of Japanese outlaws and seafarers who had established a small settlement in Cagayan, northern Luzon. ${ }^{77}$ This encounter would forever taint the official Spanish perception of Japanese merchants.

On a central level, in 1588 the leading unifier of Warring States Japan, Toyotomi Hideyoshi (r. I 582-I598), passed a law against privateering in the South China Sea. Succeeding Tokugawa rulers reenforced similar laws after rising to power in $\mathbf{I} 600$. The most prominent measure taken in order to control foreign trade was the introduction of passes showing the ruler's vermillion seal-shuinjō. Only merchant ships equipped with a seal from the central bakufu government were

\footnotetext{
${ }^{74}$ Japanese historiography has pointed to the fact that in most cases the majority of wakō were of Chinese origin. There is widespread evidence that such multiethnic merchant groups collaborated to pursue their business in the Philippines. For example, Legazpi's mentioning of both Chinese and Japanese settlers upon the arrival of the Spanish. Other Spanish sources relate that merchants who came to Manila to sell weapons were vassals of the "king" of Hirado: See AGI Filipinas I8 A, r. 5, n. 3I "Carta de Vera sobre situación, comercio ... japoneses etc." (26 June ${ }_{1587}$ ). In addition, Japanese historians have shown that Kyushu daimyō traditionally supported these illicit traders since gains from maritime trade were important income for their domains. For a recent study see Adam Clulow, "From Global Entrepôt to Early Modern Domain: Hirado, I609-164I," Monumenta Nipponica 65, no. I (2010): I-35.

${ }^{75}$ For a synthesis of Tokugawa Japan's trade with Southeast Asia see Victor Lieberman, Strange Parallels: Southeast Asia in Global Context, c. 800-1830, vol. 2, Mainland Mirrors: Europe, Japan, China, South Asia, and the Islands (Cambridge, Mass.: Harvard University Press, 2009), pp. 420-428.

${ }^{76}$ Iwao, Nanyō Nihonmachi, pp. 249-260.

77 Juan Gil, Hidalgos y Samurais, España y Japón en los Siglos XVI y XVII (Madrid: Alianza, 1991), pp. 23-24.
} 
allowed to sell their goods in Southeast Asian ports. Luzon was among the most popular vermillion seal trading ships' destinations during the first two decades of the Tokugawa reign. ${ }^{78}$ An average of two or three vessels supported the colony annually with military and nutritional necessities. Regular exchange between the two Pacific archipelagos encouraged many Japanese of different social backgrounds to make a living in Manila. According to Charles Boxer, the Japanese enjoyed a much greater freedom of trade at Manila than did the Chinese. ${ }^{79} \mathrm{How}$ ever, a closer look suggests the opposite. They were also assigned their own district in Dilao under the Franciscans' missionary supervision in I $585,{ }^{80}$ and contrary to previous assumptions they were not exempted from paying the poll tax to the royal treasury. ${ }^{81}$

What is most crucial to consider here is that roughly at the same time as silver output in the Americas peaked, Japan became the world's largest exporter of silver to China. ${ }^{82}$ The bulk of Japanese silver deposits entered China via Portuguese Macau thanks to the annual voyage of the "black ship" to Nagasaki. This brings into question the chief motivation for Japanese seagoing merchants to head toward Manila. Two hypothetical answers may be considered. The first and easy one hints at access to the Chinese market. But reality was far more complex. Analyzing Japan's early modern presence in Manila requires disentangling economic and political factors. Indeed, in economic terms, it was access to Chinese silk that led both private merchants and governing bodies to invest in voyages to Manila. ${ }^{83}$ Studying shipping records shows that exports from the Philippines to Japan consisted mainly of Chinese raw and manufactured silks, with rare European items, deerskin, and aromatic woods making up the difference. ${ }^{84}$

The second hypothetical answer, however, goes far beyond mere

${ }^{78}$ Nagazumi Yōko, Shuinsen (Tokyo: Yoshikawa Kōun, 200I), p. 4.

79 Charles R. Boxer, The Great Ship from Amacon: Annals of Macao and the Old Japan Trade, 1555-1640 (Lisbon: Centro de Estudos Históricos Ultramarinos, 1963), p. 73.

80 AGI, Filipinas 77, n. 9, "Carta del Cabildo eclesiástico de Manila sobre varios asuntos" ( Io July 1599). For the several Japanese residential areas in Manila see Shimizu Yūko, "Nihon Supein dankō ( 1624 ) no saikentō: Edo bakufu 'sakoku' taisaku no keisei katei," Rekishigaku kenkyū 5 (2009): I-I6.

81 Around the year 1600,218 tributes were collected from Japanese households in Manila. See Blair and Robertson, Philippine Islands, 27:79, I35.

82 See Murai Shōsuke, Umi kara Mita Sengoku Nihon (Tokyo: Chikuma Shinso, 1997), pp. 153-163.

${ }^{83}$ Archivum Romanum Societatis Iesu (ARSI) Jap/Sin 32, f. $3 \mathrm{v}-\mathrm{f} .4$. This questionnaire of testimonies of the "San Felipe" incident also proves the economic importance of silk from Manila.

${ }_{84}$ Tsūkō Ichiran, ed. Hayashi Akira (Osaka: Seibundō, I967), I 79: 575. 
economic reasons and includes aspects of late sixteenth-century processes of state formation based on diplomacy as a means of creating legitimacy. ${ }^{85}$ In terms of foreign relations, Japan remained rather invisible until the second half of the sixteenth century. Beginning with the reign of Hideyoshi, who challenged the Spanish self-perception, this would promptly change. Japan's aggressive external approach under the administration of the imperial commander (kanpaku $\left.{ }^{86}\right)$ Hideyoshi, including his infamous military plots against Korea and Ming China in 1592 and 1598 , stands in sharp contrast to the Tokugawa foreign policy. The early Tokugawa shoguns succeeded in repositioning the country in international affairs, thanks to elaborate diplomatic tactics. What these two different approaches had in common, however, was a strong desire to abandon the cosmos of the Chinese Middle Kingdom by establishing a Japan-centered system. In terms of foreign trade, one must not forget that several regulative measures that only materialized under the Tokugawa, such as the set of rules for shuinsen trade, were first tested by Hideyoshi. 87

The emerging Manila-based intercontinental trade suggests that the political and social entanglements of these three premodern states were far more complex than previously assumed. Bullion shipments from Acapulco were not the only driving forces supporting economic developments. In this respect it is crucial to distinguish between two things: the dynamics of the Manila galleon trade linking Asia with the Americas and Europe, on the one hand, and the economic performance of the multicultural urban community that-although often overshadowed by the bullion trade-gradually became the foundation of the Manila system, on the other hand.

For a better understanding of the far-reaching processes we should recall that conditions changed substantially in Japan as a result of the establishment of a Dutch trading post in Hirado in 1609 . As a further step, anti-Christian laws were enacted in I6r2 and I6 14, and Japan's state relations with the Portuguese of Macau and the Spanish of Manila began to decline. In I624, after several attempts to kick out Spanish missionaries, Tokugawa Japan officially broke ties with the Castilians in the Philippines.

${ }^{85}$ For Tokugawa Japan's altering course in foreign policies after the 1630 s see Ronald Toby, State and Diplomacy in Early Modern Japan: Asia in the Development of the Tokugawa Bakufu (Stanford, Calif.: Stanford University Press, I99I).

86 関白 chief advisor to the emperor.

87 Nagazumi, Shuinsen, pp. 2-5. 


\section{The Strikingly Different Political Economies Behind the Manila System}

Cross-examining the triangular Manila trade from both a European and an East Asian angle shows that none of the involved parties had the potential to turn the city into an ever-growing trading hub. In this light it should be easy to accept either that Spain, as well as China and Japan, had major difficulties to take advantage of Manila or that Manila had a hidden shortcoming. Manila's paradox becomes much easier to comprehend in the light of the three premodern states' political economies. Crucial aspects of their attitudes, motivations, and actions toward the Manila trade shall be systematically discussed below.

First, between 1565 and I 640 , China had no long-lasting maritime trading institutions. Not only did the state mostly prohibit private profit-oriented external trade, but also it failed to encourage profitmaximizing measures for the sake of the imperial treasury. On the Spanish side the situation differed in the sense that economic policies more elaborate than simply restricting trade were developed out of necessity. However, since most of these policies fell into the category of interventionism that had the ultimate objective of adding to the royal treasury, one may argue that the two states were more alike than previously assumed. As early as I 582, the Crown began to set limits for the galleon trade by prohibiting the maritime linkage between Peru and the Philippines. ${ }^{88}$ In the wake of such economic interventionism, the king was advised to introduce regulating decrees for the voyages of the Manila galleon in ${ }_{1587}$ and 1593 , with the aim of limiting the quantity of cargo and the amount of individual investment. These attempts favored the economic interests of Spanish settlers in Manila who feared competition from visiting entrepreneurs from the Americas. ${ }^{89}$ Yet, a gap between theory and reality continued to exist, while smuggling and corruption boomed.

The Japanese state, in turn, applied a combination of policies that showed elements of the policies of Habsburg Spain and Ming China. After 1600 , the Tokugawa rulers were extraordinarily efficient in reaping the benefits of state-controlled foreign trade policies but less concerned about individual merchants' rights. ${ }^{90}$ When recalling the events

\footnotetext{
${ }^{88}$ Blair and Robertson, Philippine Islands, 8:3 16-3 18.

89 Reed, Colonial Manila, p. 30.

90 Murakami Naojirō, Ikoku Nikki Shō (Tokyo: Sanshūsha, I929), p. 46; see also Tsūkō, I 79: 569-570.
} 
of 1603 , we get the impression that Chinese merchants were the only group that lacked legal protection from their motherland.

The relationship between each country's domestic policies and their financial gains from Manila warrants a closer look. Here again, we can trace similarities in the Spanish attitude and Ming China's denial of free foreign trade in favor of national security, and we therefore may conclude that Crown intervention played a part in hindering free economic development in both countries. In all aspects of the Manila trade, the main difference between the East Asian polities and Spain lies in the fact that Spanish restrictions for the Manila trade were encouraged not so much by the Crown's direct self-interest but rather by the pressure from other stakeholders in the motherland.

Although we do not know the exact size for the silver flows across the Pacific, from the perspective of Manila's commercial florescence it was crucial that China had easy access to huge amounts of silver, as this encouraged merchants from both Fujian and Haicheng to participate actively in trade in Southeast Asia. In short, in the first decades of the seventeenth century, official trade between Manila and maritime China peaked with an annual silver import total of more than one hundred thousand kilograms. ${ }^{91}$ Contemporary sources show that government restriction could not prevent the outflow of silver, so that far into the eighteenth century, more than I million pesos in circulating currency left Manila annually. ${ }^{92}$ Thus the idea of losing silver to the Chinese caused headaches in all corners of the Spanish overseas empire. Royal authorities in Manila came to realize that dealing with the Chinese was not lucrative for the colony, in that in return for silver they only received silk and ceramics of low quality. ${ }^{93}$ The high demand for Chinese products in all Spanish colonies however was not exactly an indicator that Spanish merchants would encounter permanent losses. Nevertheless it implies that from the perspective of the metropolis financial gains disappeared for the state.

91 After I 588, merchants from Haicheng and Fujian received licenses for trade with Southeast Asia. Luzon was among the most popular destinations. From 1588 onward, between thirty and forty licenses were annually issued for Luzon. See von Glahn, Fountain of Fortune, p. I 19; see also p. 123: "In 16 I I $_{1}$ 12, Chinese vessels accounted for 91.5 per cent of the total customs revenue collected at Manila, a telling indication of the Chinese dominance in the Philippine market."

${ }_{92}$ Unknown author, "Manila Mal Governada" (between I 700 and I 768 ).

93 Blair and Robertson, Philippine Islands, 6:279-280. The Spanish at Manila complained that only a very small amount of the silver sent from the Americas stayed in the Philippines, while the settlers of Mexico complained about the bad quality of Chinese silk products, which would cause price dumping. 
Thus by considering the constant overseas Spanish demand for Chinese silk, we may conclude that parts of the Spanish overseas empire were as keen on Chinese precious goods as the Chinese were on American silver. However, Ming China did not take advantage of the Spaniards' negative "balance of trade." 94 Instead, the Ming state lost potential profits to scorned private traders and never made serious attempts to turn the tables for the sake of the imperial treasury. This was by no means exceptional in Ming economic policy. With regard to the profitable exchange of silver and raw silk between Japan and China, the Japanese historian Nakajima recently hinted at gains made by Chinese and Japanese smugglers around the mid sixteenth century before the profits fell in the hands of Portuguese intermediaries who institutionalized silk and silver exchange between Macau and Nagasaki. He furthermore points out that both the Ming and Toyotomi regimes failed to generate huge direct profits from this exchange of their most precious commodities. ${ }^{95}$ Nakajima indirectly suggests that the lack of regulating mechanisms, such as laws that defined and institutions that supervised commercial exchange, harmed the "national economies" of China and Japan at the time. Whereas central Japan found a way to benefit economically from the lucrative trading environment in the Southern Seas, in Ming China the absence of statelevel maritime activities continued to exist because the empire lacked interest in organizing trade beyond the tally system.

A further key aspect in analyzing the role of the state in Manilarelated policies is diplomatic exchange, best illustrated by the political transitions in Japan. Hideyoshi's ambitious foreign policies have already been mentioned. In his correspondence with Manila, he addressed three letters to the governor-general of the Philippines and the king of Spain. ${ }^{96}$ In 1592 and 1593 , he sent his ambassador Harada Kiyemon to Manila, warning the Spanish governor about his enormous might and his intention to conquer the Philippines unless the Spanish paid tribute to Japan. ${ }^{97}$ Despite constant mutual embassies, ${ }^{98}$ relations

94 There is a huge debate going on whether "balance of trade" can be used in the modern sense of the word, while others discuss whether silver should be considered as a commodity or a currency.

${ }_{95}$ Nakajima Gakushō (pre-conference paper for the First Congress of the Asian Association of World Historians, Osaka, 2009), p. 3.

96 AGI, Filipinas I 8b, r. 2, n. I 2, "Carta de G. P. Mariñas enviando cartas de Japón" (I I June I 592).

97 Ibid.

98 The Castilian envoys were headed by Juan Cobo in 1592 and by Pedro Bautista one year later. 
on an official level were jeopardized by various misunderstandings. In I 596 this culminated into a tragic episode of Spanish-Japanese relations: the so-called San Felipe incident - the events that followed the shipwrecking of a Manila galleon on the coast of Japan. Misunderstandings and arrogance on both sides caused a stir among the Spanish crew and Japanese officials. When an increasing number of Japanbased Europeans and newly converted Japanese became involved in the conflict, Hideyoshi - who had already issued a ban on Christianity in 1587-felt impelled to bear down on the intruding Spaniards and the spread of Christianity. The following year, twenty-six Catholics, including barefoot Franciscan friars from Manila and native Japanesewere executed in Nagasaki and became known as the first martyrs on Japanese soil. ${ }^{99}$ Despite a further embassy under Luis de Navarrete, who endowed Hideyoshi with rich presents (that legendarily even included an elephant) relations with the Spaniards did not recover until Hideyoshi's death in $1598 .{ }^{100}$

Thereafter, the Tokugawa bakufu (1603-1867) established its political supremacy in Japan, based on the bakuhan system that has often been referred to as centralized feudalism, for 250 years. The first three shoguns of this era were particularly instrumental in centralizing power and determining the country's foreign policies. They focused on restricting power at the local level. Concerning the Manila trade, it is of particular interest that daimyō were no longer allowed to deal with foreign powers nor undertake military action without authorization. Instead, they had to commit their "political resources" to the bakufu by supporting official projects and submitting information. ${ }^{101}$

On a diplomatic level, Tokugawa Ieyasu was quick to take steps to establish friendly relations with the Castilians. One of the first things he did to appease the Spanish at Manila was reissue a ban on piracy. In I60 I he sent the Franciscan friar Jerónimo de Jesús as an envoy to the Spanish governor, assuring him of his intention to establish regular trade relations with the Philippines and New Spain. In a letter of I602, Ieyasu introduced the shuinjō system, as well as his wish to establish relations with New Spain. ${ }^{102}$ In 1605 , Spanish traders received offi-

99 Antonio de Morga, Sucesos de las Islas Filipinas (Manila: Ateneo de Manila, 2008), pp. $78-84$.

100 Blair and Robertson, Philippine Islands, I $0: 170-17$ I.

101 Oishi Shinzaburo, "The Bakuhan System," in Tokugawa Japan: The Social and Economic Antecedents of Modern Japan, ed. Nakane Chie and Oishi Shinzaburo (Tokyo: University of Tokyo Press, i991), p. 22.

102 Ikoku Nikki Shō, pp. 66-67. 
cial permission to do business in Japan. Friendly relations and bilateral negotiations reached their pinnacle in the year I609, owing to a sudden audience of the former governor of the Philippines, Rodrigo de Vivero y Velasco, before Tokugawa Ieyasu. The meeting was also the result of the stranding of a Manila galleon on the shores of Japan, but unlike in 1596 the Japanese held their word and did not confiscate goods nor harm anybody. After leyasu had initiated a meeting, the two state officials even worked out a bilateral contract that included beneficial conditions for both the Japanese and the Spanish of Manila. ${ }^{103}$ Despite initial good will on both sides, not a single article of their contract was fulfilled.

In terms of political economy and control of external affairs, the Japanese central government introduced a second elaborate measure to control foreign relations and reduce private gains next to the aforementioned shuinjō system. The ito wappu, also known as yarn allotment or pancada, enabled the government to benefit from trade with the European intermediaries and to determine the type of interaction with them. Both affected trade with the European powers and, in the case of the Manila trade, theoretically put the bakufu into the position of rule maker. Thus, the Tokugawa shoguns could pride themselves with achieving sustained success in centralizing foreign trade, which leads us right to the last key element of this comparative study, the long-term effects of the Manila trade.

\section{The Long Durée Implications of the Manila Trade}

As indicated above, Manila did not just encourage maritime trade but also inspired premodern search for a proper identity. In this respect, Japan offers probably the best example. Both Toyotomi Hideyoshi and Tokugawa Ieyasu felt compelled to legitimize their power in and outside Japan and sought official recognition as sovereigns. ${ }^{104}$ For centuries, China had dominated Japanese foreign affairs; however, ongoing tensions during the sixteenth century marked the beginning of a new era. Tributary trade was halted after the excesses of Japanese traders in

103 Cabezas, Siglo Ibérico, p. 319. See also Dainihon shi XII, 6:658-667. The treaty included direct Japanese trade with Mexico, closer collaboration between the bakufu and the Spaniards in Manila, as well as access to a safe harbor in Japan in the case of distress at sea.

104 Tessa Morris-Suzuki, "The Frontiers of Japanese Identity," in Asian Forms of the Nation, ed. Hans Antlöv and Stein Tønnesson (Richmond, UK: Curzon Press, 1996), pp. $4 \mathrm{I}-66$. 
I 523 in Ningbo, where two rival Japanese tributary missions affronted Chinese authorities, ${ }^{105}$ and Hideyoshi's military aggression against both Korea and their Chinese allies meant the end of bilateral relations. Consequently, Japan's political unifiers had to find allies from outside the Sinocentric world to establish, legitimize, and maintain their central power on the archipelago. Thus Europeans became a welcome substitute for the "absence of China." Furthermore the Japanese began to enjoy advantages in maritime trade thanks to indirect access to Chinese markets via European intermediaries. In this respect, Japanese dealings with the Iberians facilitated access to China and rendered tributary trade relations obsolete. In terms of legitimization, encounters with people from Europe and Southeast Asia helped the Japanese to escape the Sinocentric world-system. Once Japan considered herself no longer inferior to China, efforts were made to establish order in her international relations. ${ }^{106}$

The dual nature of the local and global in sociopolitical structures of these three premodern states had further long-term implications for Manila. In China, private (i.e., unofficial) foreign trade increased as a consequence of the country's pressing need of silver during the sixteenth century. The interesting question that follows is, why did official China not support the Chinese merchants in Manila in channelling bullion flows to China? Despite historical relations with smaller kingdoms in the region, such as tribute relationship with Butuan, a trading port on Mindanao, ${ }^{107}$ or interaction with the coastal region of Cagayan for its access to Igorot gold, Peking showed little interest in establishing official contact with the intruders from Europe in the era of the galleon trade. Nor did it respond to political change in the South China Sea in general. Government records pejoratively refer to the Castilians as red or Western yi or fan, a term used for non-Chinese, and occasionally they were accused of piracy. However, there is no evidence that Ming China objected to the new rulers of the Philippines. What is interesting is that despite acknowledging in the I570s that Luzon was not a tributary country, ${ }^{108}$ goods sent by the Spanish were handled within the frame of traditional tally trade. In the year 1576 , the assis-

${ }^{105}$ Csaba Oláh, Räuberische Chinesen und Tückische Japaner: Die Diplomatischen Beziehungen Zwischen China und Japan im 15. und I6. Jahrhundert (Wiesbaden: Harrassowitz, 2009). After profit-seeking Japanese merchants had been accused of disrespecting the Ming emperor, all trade with Japan was suspended.

106 Morris Suzuki, Frontiers, pp. 4I-48.

107 Scott, Barangay, p. I64.

108 Ming Shi-lu: http://epress.nus.edu.sg/msl/entry/Ior3, accessed 8 March 20 I I. 
tant censor-in-chief Liu Yao-hui, grand coordinator of Fujian, recorded that "the tribute memorial and local products brought by those of Luzon are submitted herewith." 109 Spanish colonial authorities in the Philippines considered such a treatment as an insult to the Spanish sovereignty. Before the Chinese authorities knew it, the governor-general put an end to the exchange of presents to make clear that Spain would not subordinate to tributary trade. ${ }^{110}$ This episode suggests a clash of Eastern and Western institutions that was complicated by the fact that neither system was flexible enough to react to it. In this context it is interesting to consider that the Dutch and other Europeans accepted a tributary barbarian status for the sake of access to the Chinese market. The Castilians were therefore an exception within European trading nations in Asia. ${ }^{111}$

While the Castilian authorities were driven by territorial interests, the Ming dynasty preferred national security through guarding and defending the country's frontiers and ensuring domestic stability over economic improvements. ${ }^{12}$ Profits therefore remained as peripheral to the state as the maritime zone itself. ${ }^{113}$ Unlike Japan, the central state in China was not willing to make major compromises for the sake of economic gains. Policymakers considered private overseas trade a major risk to domestic stability, even after the relaxation of maritime trade in ${ }_{1567}$ reduced it to a trickle. Since the state did not adapt its foreign policies to the more liberal maritime trade conditions, we tend to tone down Ming China's official objection against "liberal" foreign trade. However, as long as there were no major problems to be expected, Chinese maritime merchants were ironically the only trading group in Manila experiencing a kind of laissez-faire, since the state intervened in coastal politics only when it suspected problems. It can therefore be concluded that Ming China, against all expectations, was less "despotic" but remained a country that differed from Spain and Japan in terms of foreign trade and politics, an insight that calls for a serious study in the future.

The Ming court's quasi-rejection of profit-oriented foreign trade

109 Ming Shi-lu: http://epress.nus.edu.sg/msl/entry/ro2o, accessed I4 March 20 I I.

110 Ollé, Empresa, p. 68.

111 I think that we can learn a lot from the divergence in European commercial policies and aim to deepen our understanding in a survey in the future.

${ }_{112}$ A report of the Ministry of War of the year I604 states that South China's coasts have to be cleaned up from evil people by referring to private traders from Luzon. See Ming Shi-lu: http://epress.nus.edu.sg/msl/entry/3135, accessed 23 March 20 I I.

113 Wills, "Maritime China," pp. 204-207, 2 I 5. 
was also displayed by the absence of initiatives that would have turned the pirates of the Southern Seas into merchants. In that regard, we may consider that active networks once frustrated take advantage from their skills in less-complicated systems. It seems therefore only logical that entrepreneurs from coastal China after having left their native country would start a business in Manila or even in New Spain. ${ }^{114}$ Maritime Chinese traders did so-not only in Manila, but also in Melaka, Ayutthaya, Nagasaki, Batavia, and other Southeast Asian centers. ${ }^{115}$ Ming China's foreign maritime trade policies doubtlessly show a huge conflict of interest between Peking and coastal China. ${ }^{116}$ Several written sources from the late Ming period show that, on a local level, maritime officials were very much in favor of liberalizing foreign exchange for political and economic reasons, primarily for the sake of dampening the huge temptation of smuggling and fraud. ${ }^{117}$ During the period of increased private trade with the Spanish and the Dutch, numerous accusations of personal enrichment of tax supervisors and port officials reached Beijing, helping confirm to the court its previous suspicion of the evils of profit-oriented trade. ${ }^{118}$

\section{Conclusion}

We set out to understand how Spain, China, and Japan became entangled in Manila and what that meant for the city itself and the premodern states involved in her evolution into an early modern trading hub. For the purpose of analyzing the key elements of their Manila-related policies, I suggested focusing on the question of what had gone wrong. From a down-to-earth economic point of view it may be argued that in order to benefit economically from the Manila trade, merchants had to

114 Braudel, Civilization, p. 164 .

115 An article in a recent issue of this journal gives a detailed overview of the flexible networks that were operating in the South China Sea and its neighborhood. Craig A. Lockard, "'The Sea Common to All': Maritime Frontiers, Port Cities, and Chinese Traders in the Southeast Asian Age of Commerce, ca. 1400-1 750," Journal of World History 2 I, no. 2 (2010): 219-247.

116 See also Lin Renchuan, "Fukien's Private Sea Trade in the Sixteenth and Seventeenth Centuries," in Development and Decline of Fukien Province in the 17 th and I 8 th Centuries, ed. E. B. Vermeer (Leiden: Brill, I990), pp. I67-2 I 5 .

117 See Zhang Han's Songchuan mengyu of I 592 quoted by Nakajima Gakushō. For details refer to footnote no. 95 .

${ }_{118}$ Ming Shi-lu: http://epress.nus.edu.sg/msl/entry/3I69, accessed I I March 20 I I. 
be competitive with others in the same trade. In early modern Manila, only private or semi-private enterprises seemed to fall into that category. The states involved enacted few profit-oriented policies. Thus most business carried out in Manila was neither sustained nor sustainable. Although one may argue that the Manila galleon continued its silver journey until $18 \mathrm{I} 5$, we must not forget that its peak years were between 1590 and 1620 . What is most striking in the case of Manila was that this affected both the city itself and the states involved in this promising trade. One obvious reason was the dichotomy between private and central stakeholders. It is most likely that, unlike private merchants, all three central governments-despite their different geographical positions and political involvement-very often did not know what was going on. In that respect-with the exception of postI60o Japan-it is crucial to remember that these issues hardly ever reached the sovereign's desk but were dealt with by local government officials.

Considering long-term effects, I have also tried to show that the triangular Manila trade cannot be explained entirely by merely looking at early modern economies. As indicated at the beginning of this study, political factors were just as significant. Decision making, for instance, was affected by different ideas of sovereignty. Imperial Spain simply did not see the necessity of being competitive with the Chinese or the Japanese, who lacked hegemonic power over Manila. Despite sporadically feeling threatened by military attacks from East Asia, the Castilians never seriously considered them political challengers. In this respect the Spanish treated the East Asians differently from other Europeans in the South China Sea. Thanks to more flexible political and economic institutions and cultural empathy, the Portuguese Jesuits and the merchants of the Dutch East India Company (VOC) succeeded in outrivaling their Spanish competitors whose operations were never free of missionary zeal.

In terms of imposing policies that allowed the premodern state to control or even benefit from Manila, we may conclude that Japan was the one displaying the most efficiency. Nevertheless, the new system of diplomatic relations and the shuinjo trade in the eyes of the rulers did not sufficiently fulfill its purpose of internal and external control. This system was abolished four years before the central government refused access to their country after I 639 to all Westerners except the Dutch. By this time Tokugawa Japan had long lost its interest in dealing with the Spaniards and in enhancing its position in Southeast Asia and the transpacific trade, for important hegemonic goals had been met already. Withdrawing from the sea meant not subordinating to any 
other states' rules-neither to China's tributary system nor to highly competitive European mercantilism that had reached its peak in Asia after the arrival of the British and the Dutch at the beginning of the seventeenth century. Just as in imperial China, Japan had established its own rules-only outsiders who completely acquiesced to the Japanese terms and conditions, such as VOC merchants, were tolerated as negotiating parties.

What does that tell us about economy and state in the early modern period? In all three premodern states, governance and sovereignty held center stage and influenced developments in both the domestic and export markets that in turn had an impact on proto-globalization processes. New evidence suggests that the factors that led to different economic developments in foreign trade in Asia and Europe were not just contingent but also the product of different political motivations. While it has often been claimed that China was the overall "winner" as most of the silver ended up there, a minor change in perspective challenges the black-and-white view of the Spanish performance. Nobody will deny that tremendous amounts of silver drained off to China, but at the same time Spain benefitted both economically and politically. It earned from arbitrage in the silk trade-albeit limited-and maintained its power for several centuries regardless of major transformation processes in the East.

Returning to the question of Manila's failure in maintaining its global significance, in the case of Spain we may conclude that it was not other nations' success but the dynamics of a bulky overseas empire that caused permanent problems. Involvement in European, American, and East Asian affairs, such as protests in Spain, hegemonic competition with the Portuguese and the Dutch, and frictions with the Japanese, showed that the Philippines were difficult to integrate into the existing territory-based colonial programs that only worked with large numbers of dedicated settlers from other Spanish territories. Political maneuvering was furthermore complicated by the dualism of the Church and colonial authorities, the high degree of bureaucracy-aggravated by huge distances-and the over-restriction of the transpacific trade that encouraged smuggling and corruption.

In East Asia, Japan managed to turn economic drives into political benefits for the central government in Edo. During the early decades of the transpacific trade, both Chinese and Japanese merchants had incentives to meet and trade in Manila. The sudden withdrawal of Japan and her rigorous foreign policies after I639 have blurred historians' view on her relevance for the early modern world. When reassessing Manila's role in global history, however, we must not overlook that 
as a consequence of a successful state formation and economic restructuring, Japan's aspired hegemonic position in East Asia was redefined. Through interactions with Spain and China in the decades prior to her "closure," Japan managed to become an independent economic player and what one may label the first real premodern state in East Asia, all thanks to efficient institutions. 